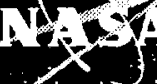

An Experimental Study of Turbulent Skin Friction Reduction in Supersonic Flow Using a Microblowing Technique

Danny P. Hwang

Glenn Research Center, Cleveland, Ohio 
Since its founding, NASA has been dedicated to the advancement of aeronautics and space science. The NASA Scientific and Technical Information (STI) Program Office plays a key part in helping NASA maintain this important role.

The NASA STI Program Office is operated by Langley Research Center, the Lead Center for NASA's scientific and technical information. The NASA STI Program Office provides access to the NASA STI Database, the largest collection of aeronautical and space science STI in the world. The Program Office is also NASA's institutional mechanism for disseminating the results of its research and development activities. These results are published by NASA in the NASA STI Report Series, which includes the following report types:

- TECHNICAL PUBLICATION. Reports of completed research or a major significant phase of research that present the results of NASA programs and include extensive data or theoretical analysis. Includes compilations of significant scientific and technical data and information deemed to be of continuing reference value. NASA's counterpart of peerreviewed formal professional papers but has less stringent limitations on manuscript length and extent of graphic presentations.

- TECHNICAL MEMORANDUM. Scientific and technical findings that are preliminary or of specialized interest, e.g., quick release reports, working papers, and bibliographies that contain minimal annotation. Does not contain extensive analysis.

- CONTRACTOR REPORT. Scientific and technical findings by NASA-sponsored contractors and grantees.
- CONFERENCE PUBLICATION. Collected papers from scientific and technical conferences, symposia, seminars, or other meetings sponsored or cosponsored by NASA.

- SPECIAL PUBLICATION. Scientific, technical, or historical information from NASA programs, projects, and missions, often concerned with subjects having substantial public interest.

- TECHNICAL TRANSLATION. Englishlanguage translations of foreign scientific and technical material pertinent to NASA's mission.

Specialized services that complement the STI Program Office's diverse offerings include creating custom thesauri, building customized data bases, organizing and publishing research results ... even providing videos.

For more information about the NASA STI Program Office, see the following:

- Access the NASA STI Program Home Page at http://www.sti.nasa.gov

- E-mail your question via the Internet to help@sti.nasa.gov

- Fax your question to the NASA Access Help Desk at (301) 621-0134

- Telephone the NASA Access Help Desk at (301) 621-0390

- Write to: NASA Access Help Desk NASA Center for AeroSpace Information 7121 Standard Drive Hanover, MD 21076 


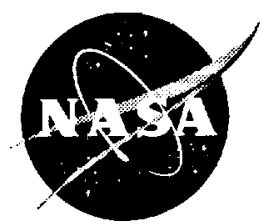

\section{An Experimental Study of Turbulent Skin Friction Reduction in Supersonic Flow Using a Microblowing Technique}

Danny P. Hwang

Glenn Research Center, Cleveland, Ohio

Prepared for the

38th Aerospace Sciences Meeting and Exhibit

sponsored by the American Institute of Aeronautics and Astronautics

Reno, Nevada, January 10-13, 2000

National Aeronautics and

Space Administration

Glenn Research Center 


\section{Acknowledgments}

This work was funded by NASA Glenn Research Center's Fast Quiet Engine (FQE) program.

Special thanks are due to Mr. David Arend who prepared the CFD design of the supersonic tunnel, and $\mathrm{Mr}$. Tony Herrmann who prepared the engineering design of the supersonic tunnel. The following individuals are also acknowledged for their contributions during the experiments: Mrs. Gwynn Severt, Mr. Scott Panco,

Mr. Carlos Gomez, and Mr. Ron Abel. Finally, the author would like to express sincere thanks to Dr. Greg Tillman of the United Technologies Research Center for reviewing the final draft and providing valuable comments.

Available from

NASA Center for Aerospace Information 7121 Standard Drive

Hanover, MD 21076

Price Code: $\mathrm{A} 03$
National Technical Information Service 5285 Port Royal Road Springfield, VA 22100 Price Code: A03 


\title{
AN EXPERIMENTAL STUDY OF TURBULENT SKIN FRICTION REDUCTION IN SUPERSONIC FLOW USING A MICROBLOWING TECHNIQUE ${ }^{*}$
}

\author{
Danny P. Hwangt \\ National Aeronautics and Space Administration \\ Glenn Research Center \\ Cleveland, Ohio 44135
}

\begin{abstract}
$\underline{\text { Abstract }}$
A new turbulent skin friction reduction technology, called the microblowing technique, has been tested in supersonic flow (Mach number of 1.9) on specially designed porous plates with microholes. The skin friction was measured directly by a force balance and the boundary layer development was measured by a total pressure rake at the tailing edge of a test plate. The free stream Reynolds number was $1.0(10)^{6}$ per meter. The turbulent skin friction coefficient ratios $\left(C_{t} / C_{f 0}\right)$ of seven porous plates are given in this report. Test results showed that the microblowing technique could reduce the turbulent skin friction in supersonic flow (up to 90 percent below a solid flat plate value, which was even greater than in subsonic flow).

\section{Symbols}

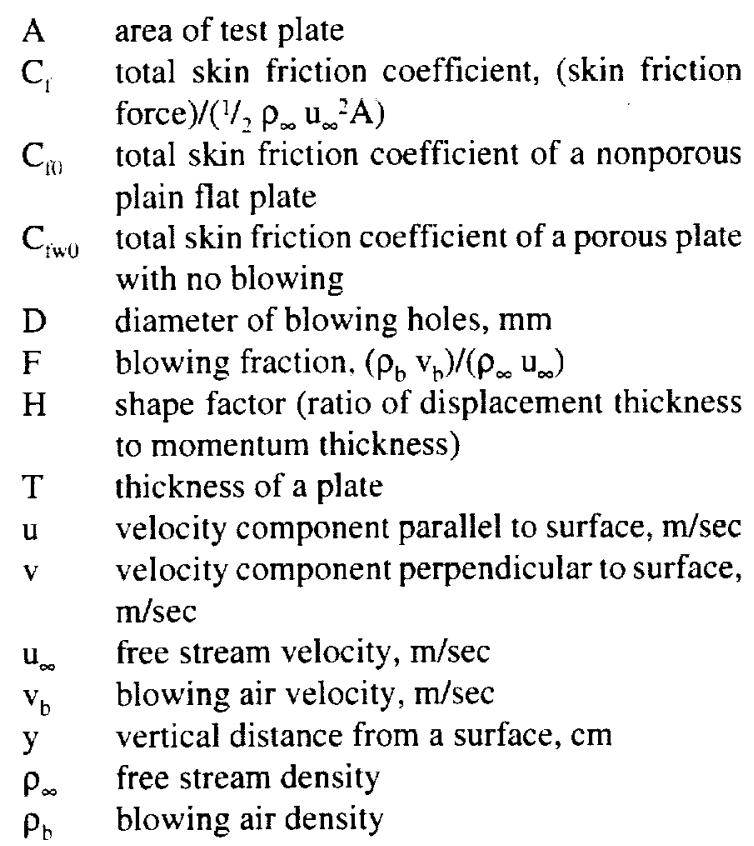

\footnotetext{
"Patent no. 5,803,410
}

'Senior member, AIAA
Introduction

One of the challenges associated with the development of a high-speed civil aircraft is the reduction of high skin friction. One technique that has received much attention for subsonic flow is laminar flow control. Its application in supersonic flow is difficult. Many other skin friction reduction techniques (summarized in Ref. 1) cannot provide significant reduction in real world applications.

One proposed solution to skin friction reduction, blowing (or surface mass injection), has been abandoned because it had problems with flow separation. Many researchers during the past 30 years have used the parameters, $2 F / C_{f w i}$ versus $C_{f} / C_{f w n}$, for their results and have shown that blowing could achieve significant skin friction reduction. ${ }^{1-3}$ However, it was not clear whether blowing could result in a reduction in skin friction below a solid flat plate value. As indicated in Ref. 4, the unblown skin friction coefficients, $\mathrm{C}_{\mathrm{f0}}$, of some porous plates were more than twice the value of a solid flat plate and it was impossible to reduce the skin friction of these plates below that of a solid flat plate.

The microblowing technique (MBT) for reducing turbulent skin friction was invented in 1994 by the author and a patent was issued in 1998. ${ }^{5}$ In this unique concept, an extremely small amount of air is blown vertically through a specially designed porous plate with microholes. The reduction in the surface roughness and the gradient of the flow velocity profile on the surface decreases skin friction.

Several experiments have been completed for subsonic flow ${ }^{5-8}$ and results showed that a turbulent skin friction reduction of up to 50 to 70 percent below the value of a solid flat plate was possible for subsonic flow if proper porous plates were used.

A proof of concept MBT experiment for reducing skin friction in supersonic flow at a Mach number of 1.9 was conducted in test facility CE22 $2^{\circ}$ at the NASA Glenn Research Center in 1999. Seven test skins (Table 1) were 
selected from the previous subsonic tests. The inner skin that was used for many subsonic tests was eliminated. The preliminary results showed that the MBT could reduce skin friction up to 90 percent below a solid flat plate value in supersonic flow.

In this paper, the detailed description of the experiment, the results of test data and the discussion of this new technology will be given.

\section{Skin Tested}

Seven test skins (Table I) were selected from the previous subsonic tests. The inner skin that was used for many subsonic tests was eliminated because it was believed that the skin friction reduction was not affected by the inner skin and also because the pressure loss across the inner plate could be eliminated. Laser drilled microholes $(0.1651 \mathrm{~mm}$ in diameter) are shown in Fig. 1 and the crosssection view of 15-degree, slanted laser-drilled holes is given in Fig. 2. Northrop Grumman GAC1897 has hourglass-shaped holes with 50 -percent porosity based on an open hole area and only has 4 percent porosity based on the small neck area as shown in Fig. 3. The schematic diagram of hole pattern showing staggered holes and aligned holes is illustrated in Fig. 4.

The size of the test plates is 12.36 by $25.06 \mathrm{~cm}$.

\section{Test Facility}

The Advanced Nozzle and Engine Components Test Facility (CE22) at NASA Glenn ${ }^{9}$ was modified for this experiment. A shock-free converging-diverging supersonic duct $109.22 \mathrm{~cm}$ long is connected to a facility transition duct with a rectangular cross-section exit of 10.8 by $20.32 \mathrm{~cm}$. The facility provided a stable Mach number of 1.9 at Reynolds number per meter of $1.0(10){ }^{6}$ The back pressure (exit pressure) was maintained as low as possible to avoid keeping the shock inside the duct for too long, which would damage the force balance.

\section{Apparatus and Instrumentation}

The force balance used in previous subsonic experiments was used for this experiment. ${ }^{4}$ Since larger skin friction and blowing air requirements were expected, a 4800-gram load cell and a 1500 SLM flow meter were used. The accuracy of the load cell used in the balance was $+1-0.25$ percent. The balance was placed under the test section inside a sealed compartment, as shown in Fig. 5. The leading edge of the test plate is located in a constant pressure region, $63.5 \mathrm{~cm}$ from the transition duct. There were two total pressure rakes along the center line of the duct. The measurement plane of rake I was located $3.2 \mathrm{~cm}$ upstream of the leading edge of the test plate while the measurement plane of rake 2 was $1.1 \mathrm{~cm}$ upstream of the trailing edge of the test plate. Rake 2 had a very small vertical gap (less than $0.2 \mathrm{~mm}$ ) between the test plate and the nearest tube. The total pressure rakes were built with tubing that had an outside diameter of $0.508 \mathrm{~mm}$. Rake 1 was removed after the data was taken to minimize the interference on the measurement of skin friction. Rake 2 was used to calculate the momentum thickness and the velocity profiles inside the boundary layer. Facility total pressure rakes, facility total temperature thermocouples, and a static pressure at the leading edge of the test plate were used to measure the tunnel Mach number.

\section{Calibration}

An identical load cell was used to calibrate the load cell inside the balance. The calibration showed that the friction of the balance was very small due to the frictionless flexural pivots. The data were adjusted during the data acquisition process for this small difference.

\section{$\underline{\text { Results and Discussion }}$}

The seven porous plates selected from previous subsonic tests (Table I) were tested in supersonic flow (Mach number of 1.9) in the region of nopressure gradient. The standard deviation of force measurement was kept below 2 grams for 15 data scans. The test results are presented herein.

The wall static pressure along the supersonic duct is shown in Fig. 6. As expected, there were no shocks in the duct because there was not an abrupt increase in pressure in the duct. The test plate was located from $x=76.2$ to $101.6 \mathrm{~cm}$ from the entrance of a transition duct. A fairly constant pressure gradient region is shown in Fig. 6, including a case with the highest blowing rate.

A solid stainless steel flat plate without microholes was first tested and the skin friction coefficient $\left(\mathrm{C}_{\mathrm{ft}}\right)$ was considered as a reference. The repeatability of the facility is shown in Fig. 7 for the results taken on April 14, 1999 and April 22, 1999. The small difference could be due to the different level of turbulence on these two days. Based on Tillman's report, ${ }^{7}$ the uncertainty of drag measurement is about 5 to 10 percent, therefore, 2 to 3 percent difference in measurement for these experiments is considered acceptable. The total skin friction coefficients obtained from this test for a plain stainless steel flat plate were compared with Ludwieg and Tillmann's empirical formula ${ }^{16}$ and is shown in Fig. 8. Keep in mind that the total skin friction coefficients from the tests being reported were the average value based on a 12.36 - by $25.06-\mathrm{cm}$ plate. The momentum thickness was based on the 
downstream total pressure rake, which was higher than the momentum thickness upstream at the center of the plate. However, the results were reasonably close.

The total skin friction coefficient of a porous flat plate $\left(\mathrm{C}_{\mathrm{fw0}}\right)$ without blowing was measured. Next, the blowing air control valve was opened to allow for different blowing air flow rates. The skin friction coefficients $\left(C_{f}\right)$ were measured at the Mach number of 1.9. Jeromin plotted $\mathrm{C}_{\mathrm{f}} / \mathrm{C}_{\mathrm{fw} 0}$ against $2 \mathrm{~F} / \mathrm{C}_{\mathrm{fw} 0}$ for many researchers' data, and showed rather scattered data. ${ }^{2}$ Many researchers also used these two parameters. Therefore the current data were first plotted in the same way as shown in Fig. 9. All skins except GAC2054 did very well and fell within Hefner and Bushnell's range. ${ }^{3}$ The GAC2054 plate was selected because it had a very low unblown skin friction coefficient $\left(\mathrm{C}_{\mathrm{fw0}}\right)$ in subsonic flow, but the skin friction reduction was not significant in supersonic flow because of the low porosity of 4 percent and conical-shaped holes. A drawback of this figure is that one cannot tell how much skin friction reduction below that of a solid flat plate has been achieved.

A more meaningful way to present test results is given in Fig. 10, where skin friction ratios $\left(C_{1} / C_{t 0}\right)$ were plotted against the blowing fraction, F. All seven porous plates, which were selected from previous subsonic tests, had a very low unblown skin friction. The data showed that skin friction ratios were close to one when $F$ was equal to zero (i.e., the skin friction of these plates without blowing was very low and close to a solid flat plate value). As expected, the skin friction ratio was reduced below that of a flat plate with very low blowing air and the skin friction continued to reduce until the limit of the flow meter was reached. The turbulent skin friction reductions of 80-90 percent below a flat plate value were achieved at the highest flow rate, $\mathrm{F}=0.004$.

In Fig. 10, a very small difference was shown between PN23 (straight vertical holes) and PN5 (15-degree slanted holes) and also between PN5 (15-degree staggered holes) and PN7 (15-degree aligned holes). This means that additional effort to drill slanted holes is not necessary and holes need not be aligned for real application.

The velocity profile obtained from the downstream boundary layer rake is shown in Fig. 11. It was very clear that blowing did reduce the flow velocity near the surface such that it reduced the viscous shear stress. The magnitude of reduction in flow velocity close to the surface is much more than that of subsonic flow. ${ }^{5}$ This could be a reason why the MBT reduced skin friction more for supersonic flow than subsonic flow.

\section{Concluding Remarks}

A very significant turbulent skin friction reduction (up to 90 percent) below a solid flat plate value has been achieved in supersonic flow using a microblowing technique. The amount of reduction is much larger in supersonic flow than in subsonic flow. The porous plates (except GAC2054), which worked very well in subsonic flow, also worked very well in supersonic flow. The inclination and alignment of holes did not seem important. This technology can be applied to many types of flows, turbulent or laminar, subsonic or supersonic.

\section{Aknowledgments}

This work was funded by NASA Glenn Research Center's Fast Quiet Engine (FQE) program. Special thanks are due to Mr. David Arend who prepared the CFD design of the supersonic tunnel, and Mr. Tony Herrmann who prepared the engineering design of the supersonic tunnel. The following individuals are also acknowledged for their contributions during the experiments: Mrs. Gwynn Severt, Mr. Scott Panco, Mr. Carlos Gomez, and Mr. Ron Abel. Finally, the author would like to express sincere thanks to Dr. Greg Tillman of the United Technologies Research Center for reviewing the final draft and providing valuable comments.

\section{$\underline{\text { References }}$}

1. Bushnell, D.M. and Hefner, J.N.: Viscous Drag Reduction in Boundary Layers. Progress in Astronautics and Aeronautics, volume 123, American Institute of Aeronautics and Astronautics, Inc., Washington, DC, 1990.

2. Jeromin, L.O.F.: An Experimental Investigation of the Compressible Turbulent Boundary Layer With Air Injection, ARC Reports and Memoranda No. 3526, Aeronautical Research Council, London, England, 1968.

3. Hefner, J.N. and Bushnell, D.M.: Viscous Drag Reduction Via Surface Mass Injection. Viscous Drag Reduction in Boundary Layers, vol. 123, Progress in Astronautics and Aeronautics. pp. 457-476, 1990.

4. Hwang,D.P.: A Proof of Concept Experiment for Reducing Skin Friction by Using a Micro-Blowing Technique, AIAA Paper No. 97-0546, 1997.

5. Hwang, D.P.: Skin Friction Reduction by Micro Blowing Technique, U.S. patent no. 5,803,410, December 1995.

6. Hwang.D.P. and Biesiadny, T.J.: Experimental Evaluation of the Penalty Associated With Micro-Blowing for Reducing Skin Friction, AIAA Paper No. 98-0677, 1998.

7. Tillman, T.G.: Drag Reduction on a Large-Scale Nacelle Using Micro-Blowing Technique, AIAA Paper No. 99-0130, 1999.

8. Hwang. D.P.: Skin Friction Reduction by a Micro-Blowing Technique, AIAA J., vol. 36, no. 3, March 1998. pp. 480-481.

9. Beltran, L.R., Del Roso, R.L., and Del Rosario, R.: Advanced Nozzle and Engine Components Test Facility. NASA TM-103684, 1992.

10. Ludwieg, H. and Tillmann, W.: Investigations of the Wall Shearing Stress in Turbulent Boundary Layers. NACA TM-1285, 1950. 
Table 1.-Specifications of test plates.

\begin{tabular}{|l|c|c|c|c|l|}
\hline Plate name & $\begin{array}{c}\text { Porosity, } \\
\text { percent }\end{array}$ & $\begin{array}{c}\text { Hole } \\
\text { diameter, } \\
\mathrm{mm}\end{array}$ & $\begin{array}{c}\text { Skin } \\
\text { thickness }\end{array}$ & $\begin{array}{c}\text { Aspect } \\
\text { ratio, } \\
\text { L/D }\end{array}$ & \multicolumn{1}{|c|}{ Description/Material } \\
\hline \hline Flat Plate & & & & & Stainless Steel \\
\hline GAC 1897 & 50 & 0.06 & 0.305 & 5.08 & Northrop Grumman's plate, nickel \\
\hline GAC 2054 & 4 & 0.13 & 0.23 & 1.769 & Northrop Grumman's plate, nickel \\
\hline PN 23 & 23 & 0.1651 & 1.016 & 6.15 & Laser drilled straight holes, stainless steel \\
\hline PN4 & 23 & 0.1651 & 1.016 & 6.15 & 5-degree angle holes, staggered, stainless steel \\
\hline PN5 & 23 & 0.1651 & 1.016 & 6.15 & 15-degree angle holes, staggered, stainless steel \\
\hline PN6 & 23 & 0.1651 & 1.016 & 6.15 & 5-degree angle holes, aligned, stainless steel \\
\hline PN7 & 23 & 0.1651 & 1.016 & 6.15 & 15-degree angle holes, aligned, stainless steel \\
\hline
\end{tabular}

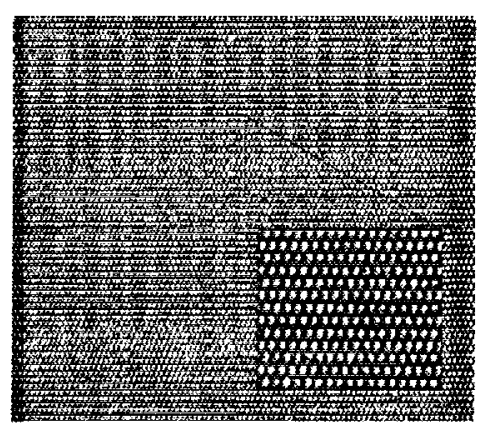

Figure 1.-Stainless-steel-laser-drilled microholes.

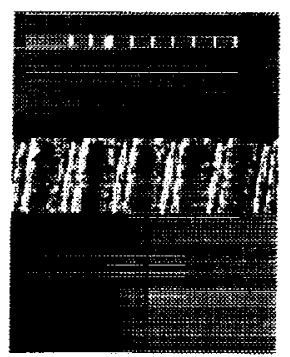

Figure 2.-Cross-section view of 15 -degree slanted-laser-drilled holes.

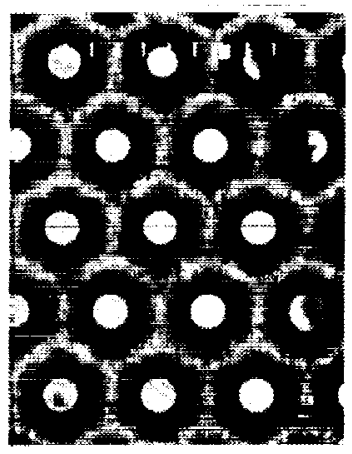

Figure 3.-Northrop Grumman GAC1897 hourglass-shaped microholes. 


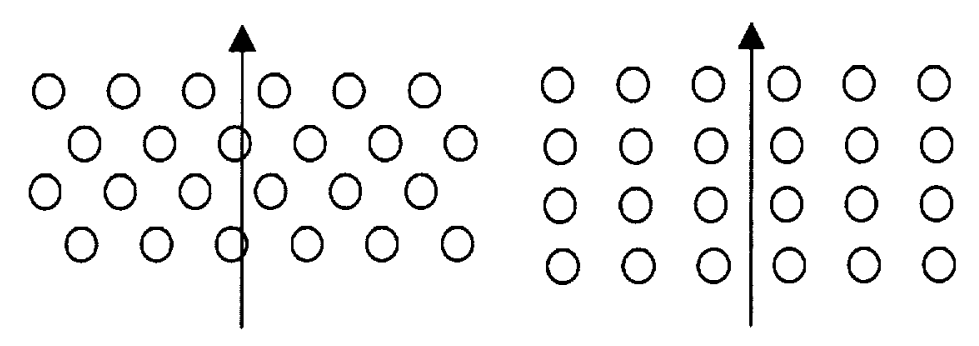

Staggered holes
Aligned holes

Figure 4.-Hole pattern.

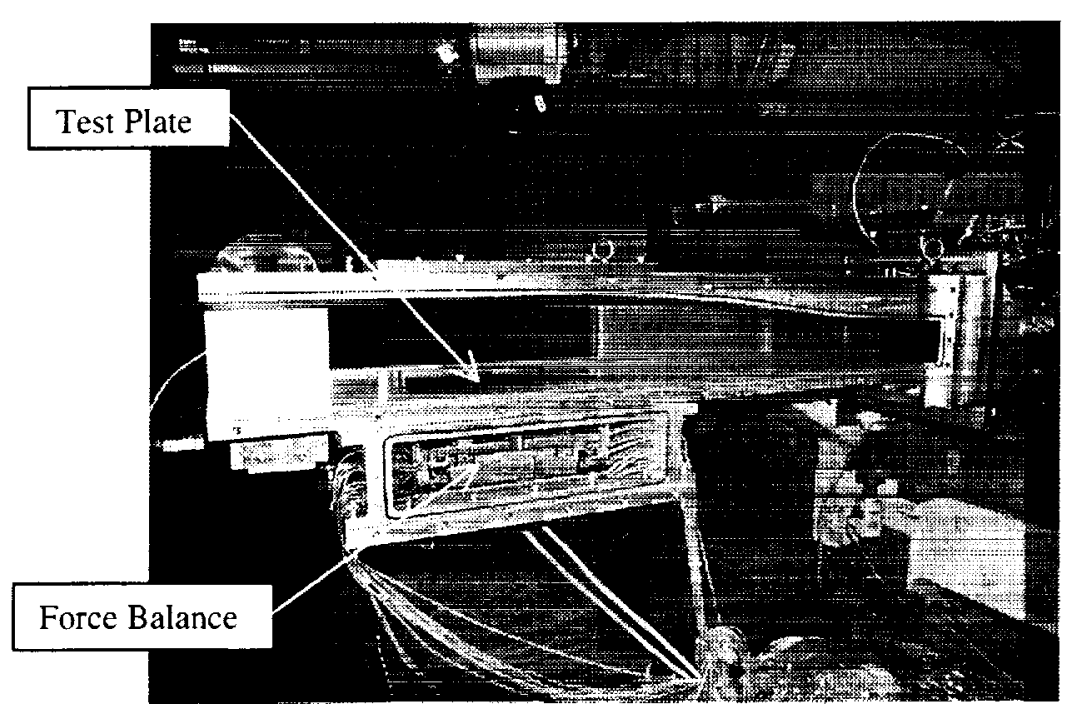

Figure 5.-Supersonic tunnel and balance.

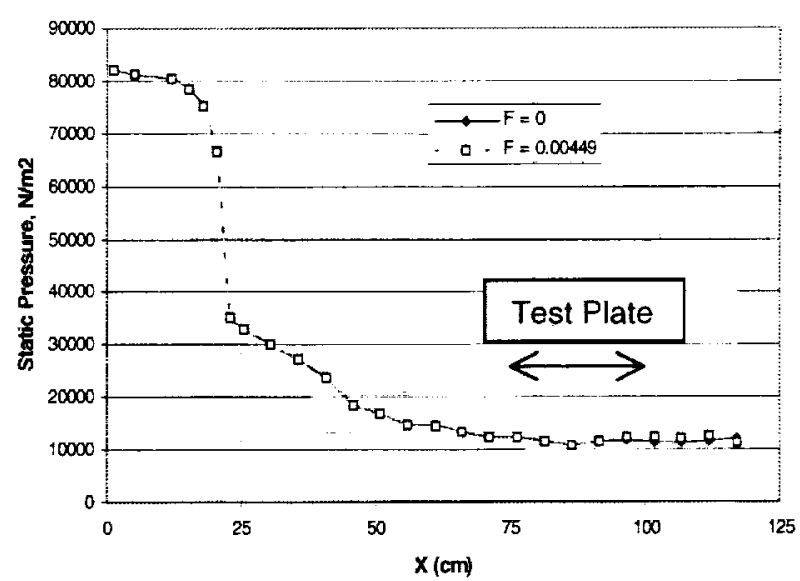

Figure 6.-Wall static pressure along supersonic duct. 


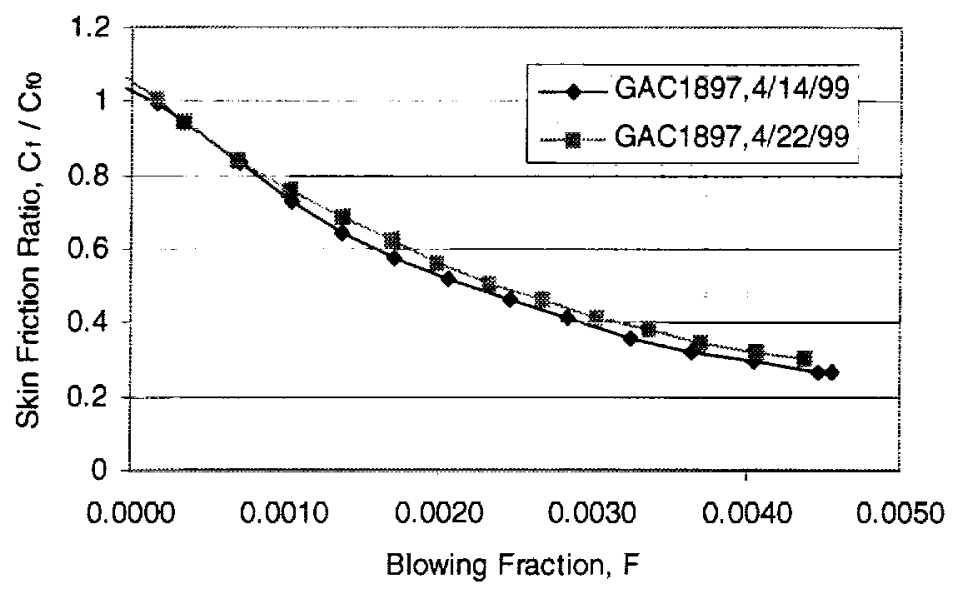

Figure 7.-Repeatability of test facility.

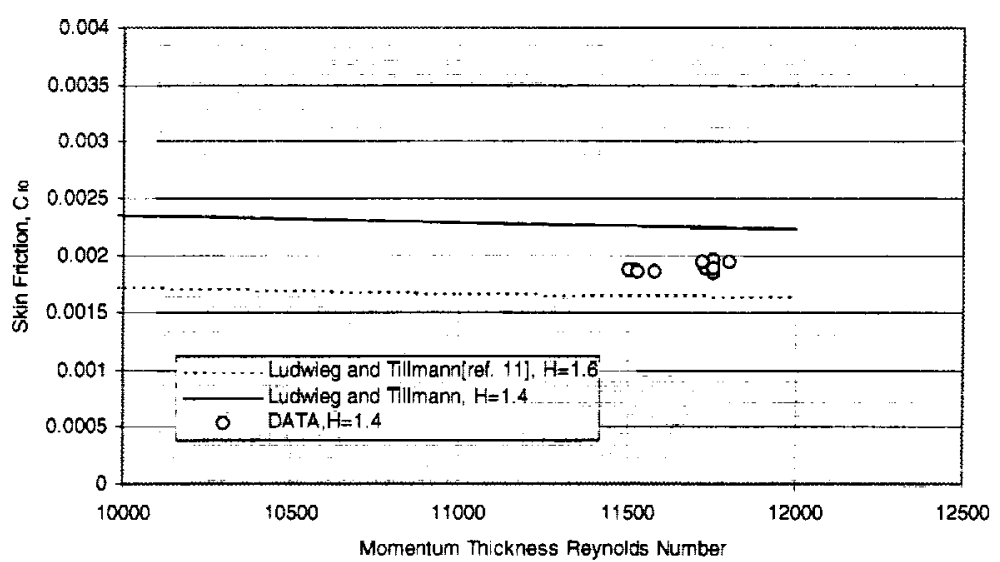

Figure 8.-Skin friction coefficient of flat plate.

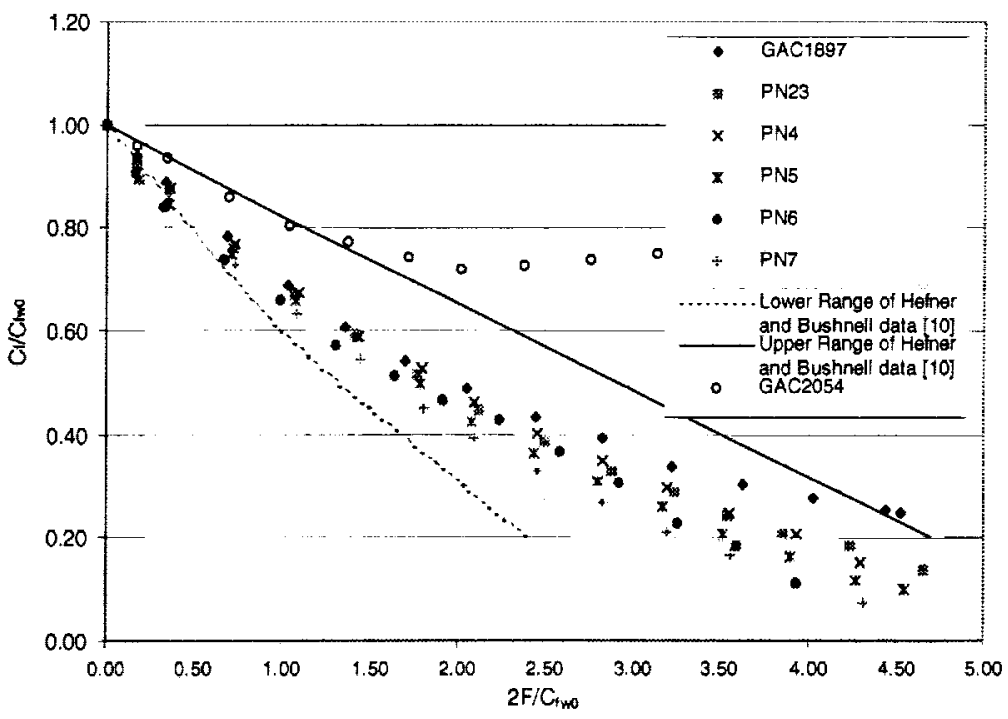

Figure 9.-Current data within range of Hefner and Bushnell data. 


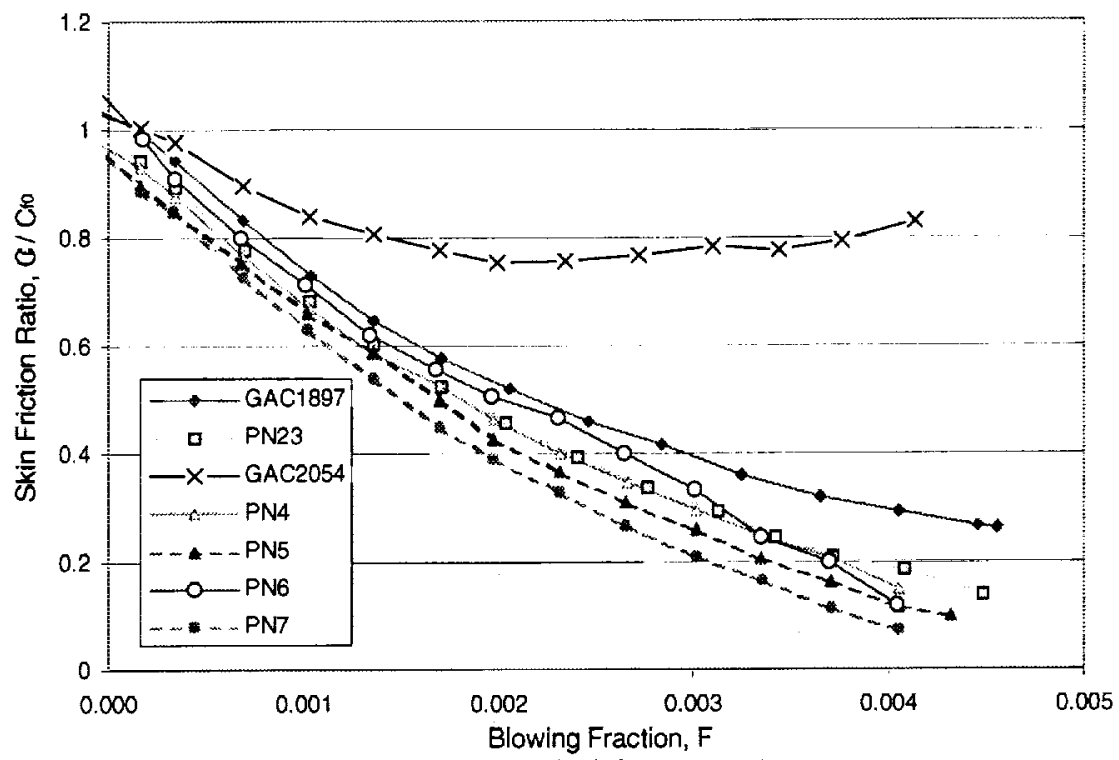

Figure 10.-Skin friction ratio of seven porous plates.

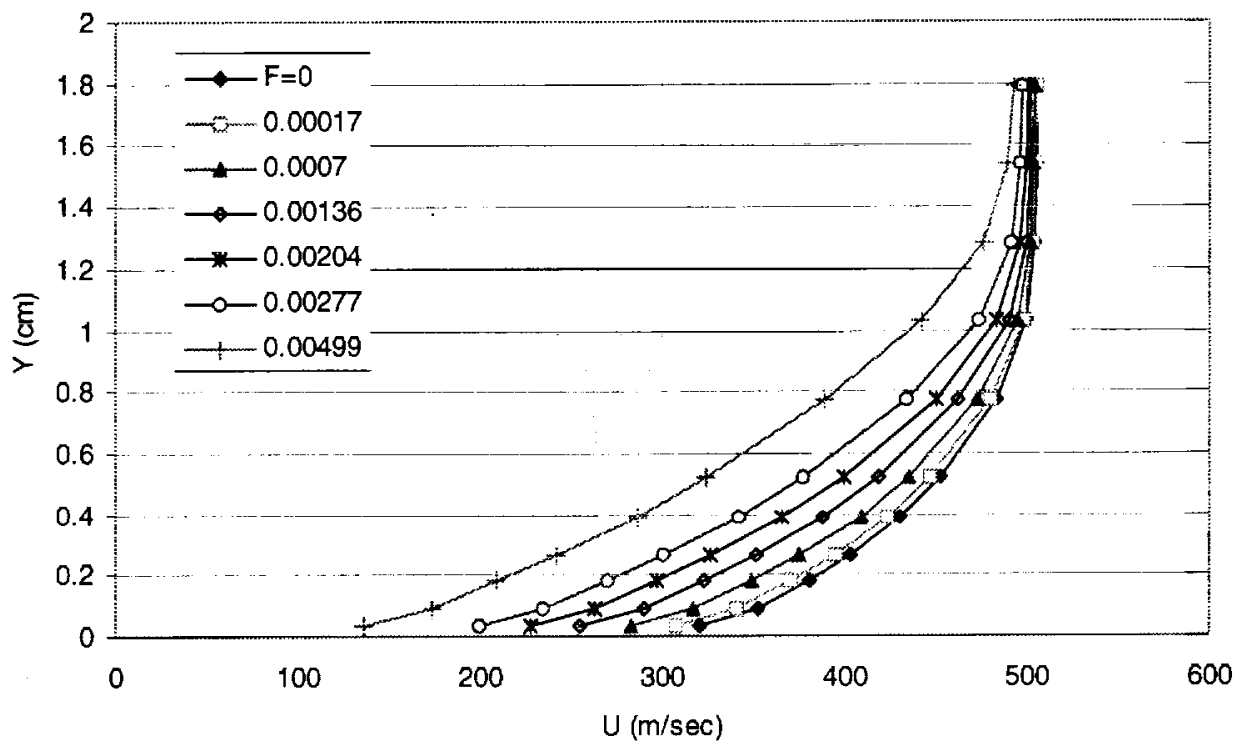

Figure 11.-Boundary layer profile at the trailing edge of PN23. 


\section{REPORT DOCUMENTATION PAGE}

Public reporting burden for this collection of information is estimated to average 1 hour per response, including the time for reviewing instructions, searching existing data sources, gathering and maintaining the data needed, and completing and reviewing the collection of information. Send comments regarding this burden estimate or any other aspect of this

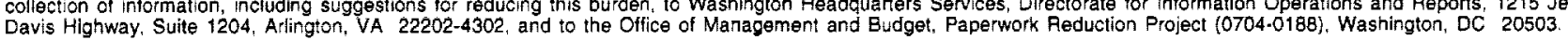

\begin{tabular}{|l|l|l}
\hline 1. AGENCY USE ONLY (Leave blank) & $\begin{array}{r}\text { 2. REPORT DATE } \\
\text { December } 1999\end{array}$ & $\begin{array}{r}\text { 3. REPORT TYPE AND DATES COVERED } \\
\text { Technical Memorandum }\end{array}$ \\
\hline
\end{tabular}

An Experimental Study of Turbulent Skin Friction Reduction in

Supersonic Flow Using a Microblowing Technique

6. AUTHOR(S)

WU-523-36-13-00

Danny P. Hwang

\section{PERFORMING ORGANIZATION NAME(S) AND ADDRESS(ES)}

National Aeronautics and Space Administration

John H. Glenn Research Center at Lewis Field

Cleveland, Ohio 44135-3191

9. SPONSORING/MONITORING AGENCY NAME(S) AND ADDRESS(ES)

National Aeronautics and Space Administration

Washington, DC 20546-0001
8. PERFORMING ORGANIZATION REPORT NUMBER

E-11959

10. SPONSORING/MONITORING AGENCY REPORT NUMBER

NASA TM-1999-209632

AIAA-2000-0545

\section{SUPPLEMENTARY NOTES}

Prepared for the 38th Aerospace Sciences Meeting and Exhibit sponsored by the American Institute of Aeronautics and Astronautics, Reno, Nevada, January 10-13, 2000. Responsible person, Danny P. Hwang, organization code 5850, (216) $433-2187$.

\section{2a. DISTRIBUTION/AVAILABILITY STATEMENT}

Unclassified - Unlimited

Subject Category: 02
Distribution: Nonstandard

\section{2b. DISTRIBUTION CODE}

This publication is available from the NASA Center for AeroSpace Information, (301) 62I-0390.

\section{ABSTRACT (Maximum 200 words)}

A new turbulent skin friction reduction technology, called the microblowing technique has been tested in supersonic flow (Mach number of 1.9) on specially designed porous plates with microholes. The skin friction was measured directly by a force balance and the boundary layer development was measured by a total pressure rake at the tailing edge of a test plate. The free stream Reynolds number was $1.0(10)^{n}$ per meter. The turbulent skin friction coefficient ratios $\left(C_{f} / C_{f v}\right)$ of seven porous plates are given in this report. Test results showed that the microblowing technique could reduce the turbulent skin friction in supersonic flow (up to 90 percent below a solid flat plate value, which was even greater than in subsonic flow).

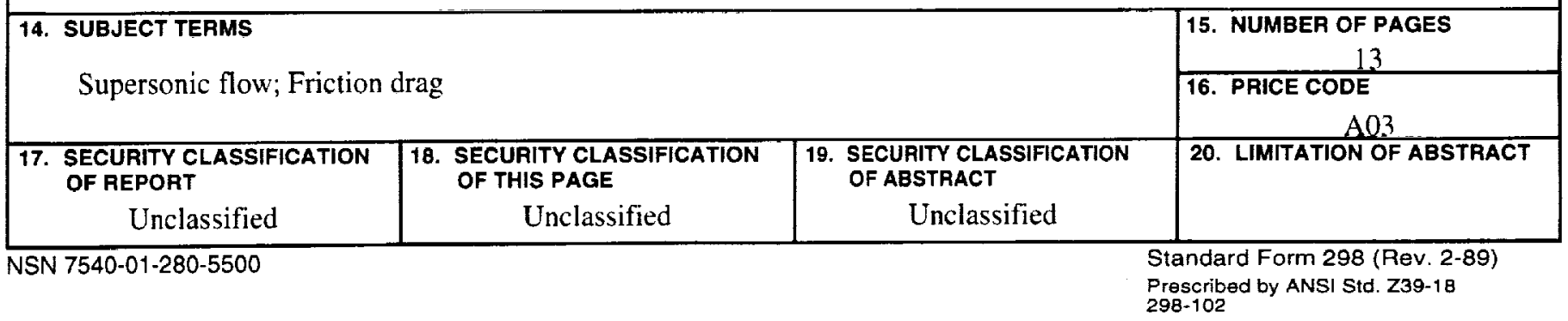

